\title{
THE EFFECT OF A VAGINAL GEL WITH HOP CONES PHYTOESTROGENS ON THE HORMONAL STATE AND MORPHOSTRUCTURE OF THE REPRODUCTIVE ORGANS IN SPAYED RATS
}

\author{
O.S.Sinitsyna, G.V.Zaychenko*, I.M.Ryzhenko, Yu.B.Laryanovska
}

\author{
National University of Pharmacy \\ Institute for Continuing Education of Pharmacy Professionals at the National University \\ of Pharmacy*
}

Key words: spayed rats; gel with hop cones; estrogen deficiency; phytoestrogens

\begin{abstract}
The article considers the results of the experimental study of the therapeutic action of a new gel with the combined composition containing phytoestrogens of the hop cones dense extract. Hypoestrogenism of animals close to that of women in menopause was simulated through bilateral spaying of females. Sham-operated animals were subjected to laparotomy and wound suturing without removal of ovaries. It has been determined that 28-days introduction of the vaginal gel results in increase of the estrogen level in the blood serum, decrease of local morphofunctional disturbances of the vaginal mucosa and the uterus in rats resulting from hypoestrogenism. The data obtained show prospects for development of vaginal drug dosage forms with the hop cones extract for treating urogenital disfunctions in the climacteric syndrome.
\end{abstract}

ccording to various authors,

Ain recent years the number of women with a pathological menopause is steadily increasing and reaches up to $60 \%$ [10].Clinicians pay much attention to prevention and treatment of menopausal disorders since the effective treatment of pathological climacteric symptoms allows retaining ability to work and proper life quality for women in the preand post-menopause period, as well as preventing development of complications [2].

Menopausal hormone therapy (MHT) with estrogens both in monotherapy and in combination with gestagenes is important when treating the climacteric syndrome. Although exogenous introduction of hormones stops the most menopause symptoms, their long-term use can cause serious side effects [12]. Women experiencing deficiency of estrogen have an increased risk of thrombosis, coronary heart disease, stroke or breast cancer [18]. No progesterone secre- tion results in the increased risk of endometrial hyperplasia and endometrial cancer [8]. One should also consider that MHT is effective in women at the early stages of the natural menopause in the period of open "therapeutic window", whereas in elderly women with comorbidity the risk of adverse reactions increases for many times [17].

In view of the previously mentioned, modern medicine and pharmacy has an important task of development of new drugs, which could complement or adequately substitute MHT in case of contraindications in women, combining the effectiveness of hormonal drugs, minimal systemic adverse reactions and protecting the target organs. Medicines with phytoestrogens entirely meet these requirements. A limited range of the latter is presented at the Ukrainian market, but there are no vaginal dosage forms at all.

The interest in prescribing phytoestrogens for women with cli-

\footnotetext{
O.S.Sinitsyna - post-graduate student of the Department of Pharmacology and Drug Toxicology of the National University of Pharmacy (Kharkiv)
}

G.V.Zaychenko - Doctor of Medicine, professor, head of the Department of Clinical Pharmacology of the Institute for Continuing Education of Pharmacy Professionals at the National University of Pharmacy (Kharkiv) macteric complaints increases every year [3]. Phytoestrogens are mostly non-steroidal polyphenolic compounds of the plant origin functionally imitating the activity of human estrogen and $17 \beta$-estradiol. The most phytoestrogens are contained in soya, red clover, flax seeds and hops [13]. The estrogenic effect of hops (Humulus lupulus L.) has been known in traditional medicine for a long time, but phytoestrogen drugs based on hops are relatively new. Extracts of hop contain 8-prenylnaringenin (8-PN) estrogenic substance and isoxantohumol - another prenyl flavonoid acting as proestrogen and metabolizing into 8-PN under the influence of the intestinal microflora $[15,16]$. According to the literature sources [14] hop extracts have a good safety profile.

It is known that the estrogen deficiency causes characteristic changes in the reproductive system: the endometrial and vaginal epithelium thinning and reduced activity of the glandular system, it occurs in dryness and thinning of the mucosa, pruritus, dyspareunia, urinary incontinence. These signs are based on decrease of the estrogen synthesis of glycosamino- 
Table

\section{The effect of the vaginal gel containing phytoestrogens of hop cones on the level of sex hormones in the blood serum in spayed female rats $(n=30)$}

\begin{tabular}{|l|c|c|}
\hline \multicolumn{1}{|c|}{ Groups of animals } & Estradiol level, $\mathrm{nm} / \mathrm{l}$ & Progesterone level, $\mathrm{nm} / \mathrm{I}$ \\
\hline Intact animals & $0.41 \pm 0.03$ & $50.91 \pm 3.64$ \\
\hline Sham-operated female rats & $0.39 \pm 0.03$ & $51.35 \pm 3.82$ \\
\hline Control pathology & $0.17 \pm 0.02^{* / * *}$ & $11.07 \pm 1.47^{* / * *}$ \\
\hline Vaginal gel with hop cones & $0.27 \pm 0.02^{* / * * * * * /+}$ & $26.46 \pm 2.41^{* / * * / * * *}$ \\
\hline Estriol suppositories & $0.39 \pm 0.02^{* * *}$ & $22.06 \pm 1.81^{* / * * / * * *}$ \\
\hline
\end{tabular}

Note:

1) * - significant for animals of IC group, $p<0.05$;

2) ** - significant for animals of SOF group, $p<0.05$;

3 ) *** - significant for animals of CP group, $p<0.05$;

4) +- significant for animals of $E$ group, $p<0.05$.

glycans as the main component of the mucus, and disturbance of the morphofunctional state of the mucous membranes of the urogenital tract [1].

In this regard, the aim of this work is to study the effect of a new vaginal gel with the hop cones dense extract (HCDE) on the hormonal panel and the morphofunctional state of the genital tract in spayed female rats.

\section{Materials and Methods}

The experimental study was performed on 30 white non-linear female rats weighing 190-195 g, they were kept in standard conditions of the vivarium of the $\mathrm{Na}$ tional University of Pharmacy on a regular diet and free access to water.

The animals were divided into five groups: intact animals (IC); sham-operated female rats (SOF); control pathology (CP); spayed rats treated with the vaginal gel with HCDE; spay animals treated with the reference drug - "Ovestin" vaginal suppositories (manufactured by Organon, the Netherlands), the active ingredient was estriol (E).

The combined gel studied containing HCDE as the main active substance, ascorbic acid and excipients has been developed at the Department of chemist's technology of drugs named after D.P. Salo of the National University of Phar- macy under the supervision of professor L.I.Vishnevskaya.

Hypoestrogenism of animals close to that of women in menopause was simulated through bilateral spaying of females according to Kirshenblat Y.D. [4]. Shamoperated animals were subjected to laparotomy and wound suturing without removal of ovaries.

Starting with the 35 th day after spaying females were introduced drugs vaginally within 28 days (daily at 9:00 a.m.): HCDE in the dose of $0.06 \mathrm{mg} / \mathrm{kg}$, E $-0.03 \mathrm{mg} / \mathrm{kg}$.

The therapeutic effect of the gel was evaluated by the level of sex hormones in the blood serum and the morphological study of the animals' lower genital tract. The most distinctive changes observed after the surgical removal of the ovaries are related to the metabolism of estradiol and progesterone $[4,11]$. Hence, the levels of these hormones were studied on an immunoassay analyzer using "Estradiol IEA" and "Progesterone IEA" standard reagent kits (Xema-Medica, Russia).

The vaginal mucosa and uterine horns were morphologically studied. The animals were euthanized by decapitation under chloroform anesthesia. The test material was fixed in $10 \%$ formalin solution, dehydrated in alcohols with the increasing concentration and poured to celloidin-paraffin.
Sections of the vagina and uterus were stained with hematoxylineosin $[6,9]$. Microslides were examined using the Granum microscope, and the microscopic pictures were taken by a Granum DSM 310 digital video camera. Pictures were processed with Pentium 2,4 GHz PC using ToupView software [7]. The experimental data were processed by the variation statistics method using "Statistica 6.0" standard software package. Average values were calculated using Student's t test.

The studies were conducted in compliance with the rules of the European Convention for the Protection of Vertebrate Animals used for Experimental and Other Scientific Purposes (Strasbourg, 1986) [5].

\section{Results and Discussion}

The data of the enzyme immunoassay of the blood serum show that the level of sex hormones (estradiol and progesterone) in females after spaying significantly decreased (Table). It indicates the relevance of the bilateral spaying model performed and formation of the experimental hypoestrogenism in rats.

The level of both hormones in the SOF group of animals, which ovaries had not been affected during surgery, was the same as in the IC group of rats.

Meanwhile, animals of the $\mathrm{CP}$ group had statistically significant decrease of the estradiol level in 2.5 times and the progesterone level in 4.6 times (in relation to the healthy rats).

The 28-days introduction of the vaginal gel with the HCDE had a moderate effect on the level of sexual hormones. However, being 1.5 times $(\mathrm{p}<0.05)$ higher than that of female rats in the CP group, the estradiol level in the blood serum in animals of this group was even below the values of the IC group. But the progesterone level in the drug under study was markedly increased, and significantly (2.4 times) exceeded the 

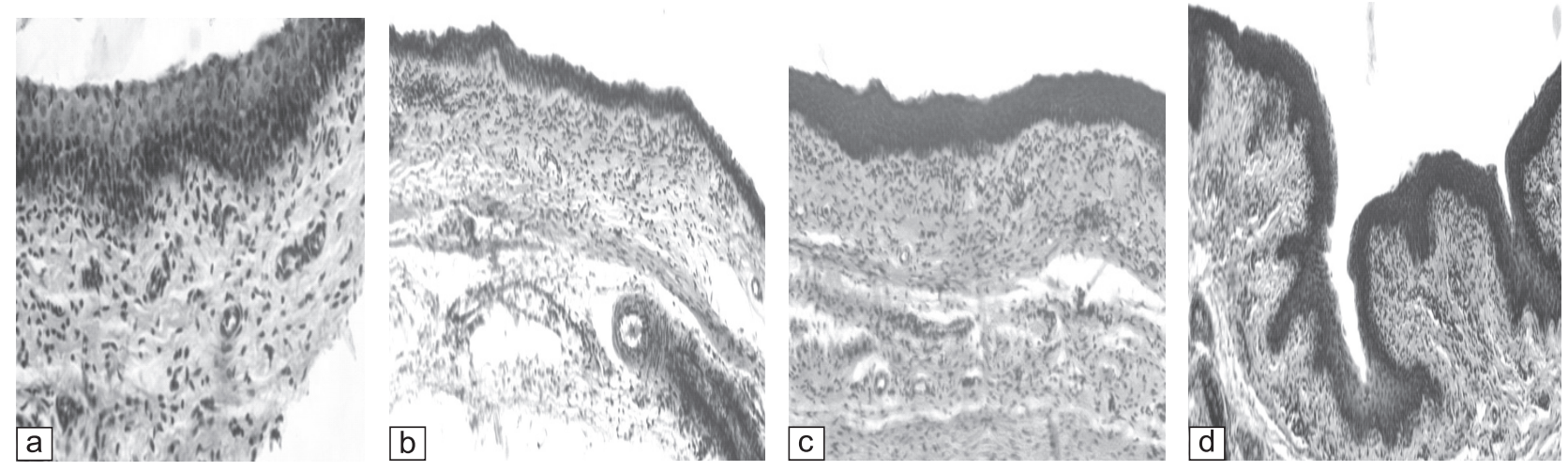

Fig. 1. Microscopy of the vagina state in the groups under study: $a$ - intact control; $b$ - spayed rats; $c$ - rats treated with the vaginal gel with the hop cones dense extract; $d$ - rats treated with the estriol suppositories (x250). Hematoxylin-eosin

index of the untreated animals (the CP group). At the same time, there were statistically significant differences in the gestagen content in the serum blood of the experimental animal compared to the data of the IC group, and there were no differences with the reference drug.

The estradiol level in the animal blood serum after the course of treatment with E suppositories had no significant differences with the similar indicator of the healthy animals. This drug had an insignificant effect on the progesterone level: this effect was almost 2.5 times less than that of the intact group of animals.

The data obtained show that none of the drugs under research could completely restore the blood serum hormonal balance (the level of sex hormones). The vaginal gel with hop cones phytoestrogen moderately increased the level of estradiol and progesterone. The re- ference drug - suppositories containing E was capable to correct hypoestrogenism and had a little effect on the progesterone level.

The morphological studies have shown that the structure of the reproductive organs studied in intact and sham-operated animals has no significant differences and is consistent with the physiological norm.

The vaginal mucosa of animals in the IC and SOF group had the structure corresponding to their age physiological norm, i.e. no mucous epithelium degeneration or disorders were observed (Fig. 1a). After bilateral spaying the mucosa underwent atrophic changes. Its vascularization was significantly reduced, a part of blood vessels became spasmodic, the vascular wall was thickened (Fig. 1b). The use of phytoestrogen vaginal gel contributed to the vaginal epithelium restoration. The epithelial layer of the distal sheath was significant- ly increased compared to the spayed animals. The blood supply was improved in the proper mucous plate (Fig. 1c). MHT with E suppository in all animals resulted in complete recovery of the morphological structure of the vaginal mucosa (Fig. 1d).

The uterus endometrium of intact animals was also within the physiological norm. The structure of the tissues could be clearly seen. The vascular profile was not broken (Fig. 2a). There was a severe atrophy in the uterus tissues of the spayed female rats. Both the endometrium and the myometrium changed. Thinning of tissues, reduction of the secretory activity of the surface epithelium cells and the epithelial uterine glands and vasospasm were observed (Fig. 2b). The drug studied had a clear positive impact on the microscopic structure of the uterus in animals. The stroma was much wider than that of the rats in the IC group. Glandular cells were of
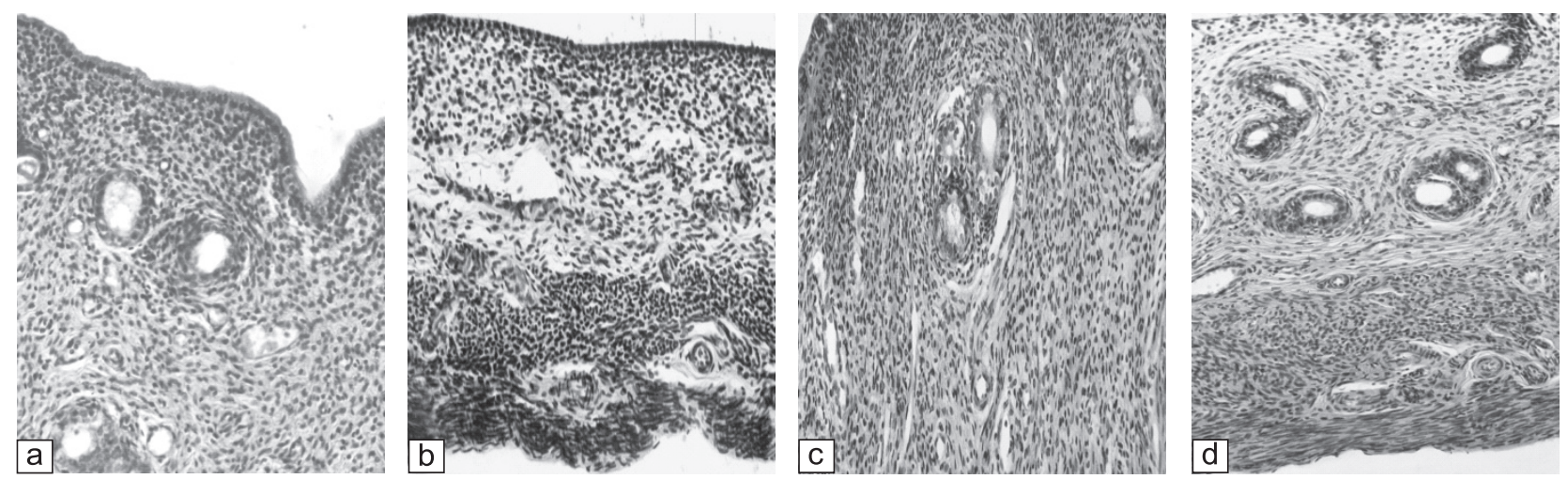

Fig. 2. Microscopy of the uterine endometrium and myometrium in the groups under study: a - intact control; $\mathrm{b}$ - spayed rats; $\mathrm{c}$ - rats treated with the vaginal gel with the hop cones dense extract; $\mathrm{d}$-rats treated with the estriol suppositories (x250). Hematoxylin-eosin 
various sizes and were structurally active; vessels were in normal state (Fig. 2c). The group of animals treated with the reference drug E had the complete restoration of the structure of the endometrium and myometrium. The state of glandular and stromal cells, blood vessels was similar with that of females of the IC group (Fig. 2d).

Thus, in 4 months after bilateral spaying female rats showed a severe atrophy of the vaginal wall and the uterine horns. A strong estrogen deficiency contributed to formation of the endothelial dysfunction signs (vasoconstriction, thickening, edema, loosening of the vascular wall, lobular proliferation, the endothelium destruction, en- dothelial picket fence location, signs of incipient thrombosis).

The gel with phytoestrogens prevented development of the above-mentioned pathologies in the experimental animals. The morphological state of the vaginal mucosa, the endometrium and the myometrium, the nature of the blood supply to the reproductive organs were similar to those of the intact rats. The estrogen effect of the HCDE gel on these animals was at the level of the reference drug suppositories containing E.

CONCLUSIONS

1. The 28-day administration course of the vaginal gel with the hop cones dense extract in the dose of $0.06 \mathrm{mg} / \mathrm{kg}$ in spayed rats causes a moderate increase of the level of sex hormones (estradiol and progesterone) in the blood serum. The reference drug, estradiol suppositories, in the dose of $0.03 \mathrm{mg} / \mathrm{kg}$ eliminates the hypoestrogenemic state, but has little effect on the gestagen amount.

2. Application of the gel with phytoestrogens of hop cones contributes to restoration of the morphological structure of the reproductive organs (vagina, uterus) subjected to degenerative changes due to estrogens deficiency at the level of the reference drug.

3 . The drug under research is promising for further study with the aim of using it in combination with other drugs for the menopausal hormone therapy in women with the climacteric syndrome.

\section{REFERENCES}

1. Воронин К.В., Потапов В.А. Пособие по практическому освоению акушерства и гинекологии. 2001. $-128 \mathrm{c}$.

2. Де Н.В., Хрипунова Г.И. // Саратовский науч.-мед. журн. - 2008. - №3 (21). - С. 125-130.

3. Карпович О.В., Гуменюк Р.Л., Ордиянц И.М. и др. // Вестник РУДН, сер. Медицина. Акушерство и гинекология. - 2005. - №4 (32). - С. 154-158.

4. Киршенблат Я.Д. Практикум по эндокринологии. - М., 1969. - С. 55-57.

5. Кожем'якін Ю.М., Хромов О.С., Філоненко М.А., Сайфетдинова Г.А. Науково-практичні рекомендації з утримання лабораторних тварин та роботи з ними. - К.: Вид. дім «Авіценна», 2002. - 156 с.

6. Колодийчук Е.В., Мернова В.П. // Журн. научных статей «Здоровье и образование в ХХІ веке».2012. - Выn. №2 (T. 14). - C. 69-73.

7. Меркулов Г.А. Курс патолого-гистологической техники. - М.: Медицина, Ленингр. отд-ние, 1969. $-424 c$.

8. Серов В.Н. // Рус. мед. журн. - 2002. - №18, сентябрь. - С. 791.

9. Смирнов А.В., Паньшин Н.Г., Спасов А.А. и др. // Бюлл. Волгоградского научного центра РАМН. 2010. - №3. - C. 14-16.

10. Тихомиров А.Л. // Фарматека. - 2007. - №10. - С. 37-41.

11. Baber R.J. // Climacteric. - 1999. - №2 (2). - P. 85-92.

12. Canonico M. // The ESTHER Study, Journal of Thrombosis and Haemostasis. - 2006. - №4 (6). - P. 1259-1265.

13. Cos P., De Bruyne, Apers S. // Planta Med. - 2003. - Vol. 69. - P. 589-599.

14. Erkkola R., Vervarcke S., Vansteeland S. et al. // Репродуктивная эндокринол. - 2011. - №2. - C. 72-78.

15. Milligan S.R., Kalita J.C., Heyerick A. et al. // J. Clin. Endocrinol. Metab. - 1999. - Vol. 84. - P. 2249-2252.

16. Possemiers S., Bolca S., Grootaert C. et al. // J. Nutr. - 2006. - Vol. 136.- P. 1862-1867.

17. Rosano G.M. // Climacteric. - 2006. - Vol. 9. - P. 19-27.

18. Vickers M.R. // BMJ. - 2007. - Vol. 335 (7613). - 239 p. 


\section{ВПЛИВ ВАГІНАЛЬНОГО ВВЕДЕННЯ ГЕЛЮ З ФІТОЕСТРОГЕНАМИ ШИШОК ХМЕЛЮ НА ГОРМОНАЛЬНИЙ СТАТУС ТА МОРФОСТРУКТУРУ РЕПРОДУКТИВНИХ ОРГАНІВ ОВАРІОЕКТОМОВАНИХ САМОК ЩУРІВ}

\section{О.С.Сініцина, Г.В.Зайченко*, І.М.Риженко, Ю.Б.Лар'яновська}

Національный фармацевтичний університет, Інститут підвищення кваліфікації спеціалістів фармації Національного фармацевтичного університету*

Ключові слова: оваріоектомовані самки щурів; дефіцит естрогенів; гель з екстрактом шишок хмелю; фітоестрогени

Розглянуті результати експериментального вивчення ефективності лікувальної дії нового гелю комбінованого складу, що містить фітоестрогени густого екстракту шишок хмелю. Моделювання у шурів гіпоестрогенового стану, близького до такого у жінок у період менопаузи, відтворювали шляхом білатеральної оваріоектомії самок. Хибнооперованим тваринам проводили лапаротомію і ушивання рани без видалення яєчників. Встановлено, що 28-денне введення вагінального гелю призводить до збільшення вмісту естрогенів у сироватці крові, зменшення локальних морфофункціональних порушень у слизовій оболонці піхви і в матці щурів, які розвинулися внаслідок гіпоестрогенії. Отримані дані відкривають перспективи розробки вагінальних лікарських форм з екстрактом шишок хмелю для лікування урогенітальних порушень при клімактеричному синдромі.

\section{ВЛИЯНИЕ ВАГИНАЛЬНОГО ГЕЛЯ С ФИТОЭСТРОГЕНАМИ ШИШЕК ХМЕЛЯ НА ГОРМОНАЛЬНЫЙ СТАТУС И МОРФОСТРУКТУРУ РЕПРОДУКТИВНЫХ ОРГАНОВ ОВАРИОЭКТОМИРОВАННЫХ КРЫС}

\section{О.С.Синицына, А.В.Зайченко*, И.М.Рыженко, Ю.Б.Ларьяновская}

Национальный фармацевтический университет, Институт повышения квалификации специалистов фармации Национального фармацевтического университета*

Ключевые слова: овариоэктомированные самки крыс; дефицит эстрогенов; гель с экстрактом шишек хмеля; фитоэстрогены

Рассмотрены результаты экспериментального изучения эффективности лечебного действия нового геля комбинированного состава, содержащего фитоэстрогены густого экстракта шишек хмеля. Моделирование у крыс гипоэстрогенового состояния, близкого к таковому у женщин в период менопаузы, воспроизводили путем билатеральной овариоэктомии самок. Ложнооперированным животным проводили лапаротомию и ушивание раны без удаления яичников. Установлено, что 28-дневное введение вагинального геля приводит к увеличению содержания эстрогенов в сыворотке крови, уменьшению локальных морфофункциональных нарушений в слизистой оболочке влагалища и в матке крыс, которые развились вследствие гипоэстрогении. Полученные данные открывают перспективы разработки вагинальных лекарственных форм с экстрактом шишек хмеля для лечения урогенитальных нарушений при климактерическом синдроме.

Address for correspondence:

12, Kulikovska str., Kharkiv, 61002, Ukraine.

Tel. (50) 633-48-88. E-mail: ksu.sinitsyna@mail.ru.

National University of Pharmacy 